\title{
PERMAINAN LUDO SEBAGAI UPAYA MENINGKATKAN KEMAMPUAN BERPIKIR KREATIF SISWA SEKOLAH DASAR
}

\author{
Visca Elya Anastasya, Ristiyani, dan Nur Fajrie \\ Universitas Muria Kudus \\ Email: viscaelyaanastasya@gmail.com
}

\section{Info Artikel}

Sejarah Artikel:

Diserahkan 27 Juli 2020

Direvisi 30 Juli 2020

Disetujui 04 Agustus 2020

Keywords:

Ludo game,

Creative Thinking,

Elementary school students

\section{Abstract}

The purpose of this study iwas to analyze the ludo game as an effort to improve the creative thinking skills of elementary school students.

Research conducted using classroom action research. The study was conducted in two cycles. The subject of research is the fifth grade students of SDN Jakenan with 24 students. Data colectiontechniques used are observation, interviews, evaluation test and documentation. The validity of the data used expert judgment techniques. Analysis of the data used is the analisysis of qualitative and quantitative data.

Based on the aspect of creative thinking the value in the cycle I obtained an average of 76,79 in Indonesia content and IPS content an average of 79,37. Cycle II the value of Indonesian Content gained an average of 81 and the IPS content obtained an average value of 86,37. Whereas the ludo game obtained an average in cycle I of $74 \%$ and cycle II gained an average of $82 \%$.

\begin{abstract}
Abstrak
Tujuan penelitian ini untuk menganalisis permainan ludo sebagai upaya meningkatkan kemampuan berpikir kreatif siswa sekolah dasar.

Penelitian yang dilakukan menggunakan penelitian tindakan kelas. Penelitian dilakukan dengan dua siklus. Subjek penelitian yaitu siswa kelas V SDN Jakenan dengan jumlah 24 siswa. Teknik penggumpulan data yang digunakan yaitu observasi, wawancara, tes evaluasi dan dokumentasi. Validitas data menggunakan teknik expert judgment. Analisis data yang digunakan yaitu analisis data kualitatif dan kuantitatif.

Berdasarkan aspek berpikir kreatif nilai pada siklus I memperoleh rata-rata 76,79 pada muatan Bahasa Indonesia dan muatan IPS memperoleh rata-rata 79,37. Siklus II nilai Muatan Bahasa Indonesia memperoleh rata-rata 81 dan muatan IPS memperoleh nilai ratarata 86,37 . Sedangkan pada permainan ludo memperoleh rata-rata pada siklus I sebesar $74 \%$ dan siklus II memperoleh rata-rata $82 \%$.
\end{abstract}




\section{PENDAHULUAN}

Dunia pendidikan sekarang ini masih didominasi dengan aktifnya guru dalam menjelaskan materi pembelajaran. Sedangkan pada kurikulum 2013 menganjurkan siswa untuk lebih aktif mengikuti pembelajaran dibandingkan guru dalam ceramah. Pembelajaran yang ideal adalah pembelajaran dimana siswa terlibat aktif dalam kegiatan pembelajaran. Keterlibatan secara aktif dalam pembelajaran akan memberikan dampak positif terhadap peningkatan kemampuan siswa. Siswa akan terbiasa untuk berpikir, berdiskusi, berpendapat dalam kegiatan pembelajaran. Sedangkan, pembelajaran yang masih didominasi oleh guru membuat siswa malas untuk melakukan kegiatan berpikir. Siswa lebih terpacu oleh jawaban yang ada di sebuah bacaan dibandingkan menggunakan kemampuannya dalam berpikir kreatif. Kondisi yang seperti itu tidak akan berubah apabila proses pembelajaran masih berpusat kepada guru. Pembelajaran seperti itu dapat mempengaruhi nilai siswa dalam mengerjakan soal evaluasi.

Hasil observasi dan wawancara yang dilakukan pada kelas V SDN Jakenan menunjukkan siswa tidak bisa berkonsentrasi karena merasa bosan dengan materi yang sangat banyak. Hal tersebut dapat dikontrol jika guru menggunakan media pembelajaran. Kondisi tersebut mempengaruhi nilai tes evaluasi berpikir kreatif siswa dari jumlah 24 siswa hanya 8 siswa mendapat nilai tuntas pada muatan pelajaran Bahasa Indonesia dan 10 siswa tuntan pada muatan pelajaran IPS.

Munandar (2014) menyatakan bahwa proses berpikir kreatif adalah menjajaki berbagai kemungkinan jawaban atas suatu masalah dan jarang bisa diukur. Menurut Rhosalia, dkk (2016) bahwa tingkat kemampuan berpikir kreatif siswa tersebut ditentukan oleh 4 indikator yaitu kelancaran, kerincian, fleksibilitas, dan originalitas.Pendapat ahli di atas dapat disimpulkan bahwa proses berpikir kreatif merupakan upaya untuk menemukan solusi yang menarik untuk menyelesaikan suatu masalahan. Dengan begitu siswa dapat menemukan hal-hal baru yang mereka dapat dari proses berpikir kreatif. Berpikir kreatif penting bagi siswa sebagai bekal siswa dalam membantu untuk memecahkan permasalahan dengan cara yang kreatif dalam kehidupan sehari-hari.

Siswa yang selalu menggunakan kemampuan berpikir kreatifnya cenderung memiliki rasa keingin tahuan yang tinggi untuk menemukan solusi dalam menyelesaikan masalah (Wulandari dkk, 2019). Menurut Lestari (2015) indikator-indikator berpikir kreatif ada 4 yaitu kelancaran, kerincian, fleksibilitas, dan originalitatas. Berikut adalah penjelasan dari masing-masing indikator. Kelancaran merupakan kemampuan yang dimiliki siswa untuk menemukan berbagai jawaban/gagasan. Kerincian adalah kemampuan siswa dalam merinci detail-detail tertu dalam menganalisis suatu bacaan. Fleksibilitas adalah kemampuan memberikan arahan yang luwes dan berbeda. Sedangkan Originalitas merupakan banyaknya variasi sebuah jawaban yang diperoleh siswa dalam kemampuan untuk memberikan jawaban yang tidak lazim, lain dari yang lain yang jarang diberikan oleh siswa.

Kemampuan berpikir kreatif siswa yang masih rendah harus dapat diperbaiki dengan pembelajaran yang lebih aktif, kreatif, efektif dan menyenangkan (Mursidik dkk, 2015). Salah satunya dengan cara penggunaan media dalam proses pembelajaran agar dapat meningkatkan kemampuan berpikir kreatif siswa yang lebih baik lagi. Media permainan ludo merupakan salah satu media permainan yang dapat menciptakan pembelajaran aktif, kreatif, efektifm dan menyenangkan. Dalam penelitian ini menggunakan media permainan ludo dalam memperbaiki kualitas proses pembelajaran yang ada di SDN Jakenan. Menurut Hapsari (2015) ludo adalah permainan edukatif yang disertai gambar-gambar berkaitan dengan materi IPS. Dari pendapat diatas dapat disimpulkan bahwa permainan ludo sangat efektif digunakan dalam melatih proses kemampuan berpikir kreatif siswa sehingga pembelajaran lebih aktif dan menyenangkan bagi siswa.

Penggunaan media ludo dapat digunakan sebagai upaya untuk meningkatkan kemampuan berpikir kreatif siswa. Kemampuan berpikir kreatif siswa dapat dilihat dari pembelajaran yang dilakukan pada tema 6 subtema 1 . Pembelajaran Bahasa Indonesia dan IPS sangat baik digunakan unruk melakukan proses berpikir kreatif dengan bantuan permainan ludo. Siswa dapat belajar mengolah kemampuan berpikir kreatif yang lebih baik lagi dengan adanya media dan pembelajaran yang kreatif. Hasil tes evaluasi juga dapat berpengaruh apabila proses berpikir kreatif siswa rendah sehingga siswa dapat memperbaiki kemampuan berpikir kreatif melalui suatu bacaan serta pertanyaan yang menantang dalam muatan Bahasa Indonesia dan IPS. Penggunaan media permainan ludo ini diharapkan dapat meningkatkan kemampuan berpikir kreatif siswa sekolah dasar.

Tujuan dalam penelitian ini adalah untuk menganalisis permainan ludo sebagai upaya meningkatkan kemampuan berpikir kreatif siswa sekolah dasar. 


\section{METODE PENELITIAN}

Metode penelitian yang digunakan dalam penelitian ini adalah metode penelitian tindakan kelas. Penelitian ini dilakukan dengan dua siklus. Tahapan dalam siklus ini terdiri dari perencanaan, pelaksanaan, pengamatan dan refleksi. Setiap siklus terdiri dari 2 pembelajaran.

Penelitian ini dilaksanakan di SDN Jakenan dengan subjek penelitian ini adalah siswa kelas V SDN Jakenan. Jumlah siswa kelas $\mathrm{V}$ yaitu 24 siswa. Sumber data diperoleh dari guru dan siswa. Teknik pengumpulan data yang digunakan dalam penelitian ini adalah teknik observasi, wawancara, tes, dan dokumentasi. Instrumen yang digunakan dalam penelitian ini lembar wawancara, lembar observasi, tes evaluasi. Teknik analisis data yang digunakan dalam penelitian ini adalah analisis data kualitatif dan kuantitatif deskriptif.

\section{HASIL DAN PEMBAHASAN}

Penelitian dilakukan dengan menggunakan beberapa tahapan dalam setiap siklusnya yaitu tahap perencanaan, pelaksanaan, observasi, dan refleksi. Pada tahap perencanaan dilakukan perencanaan yang matang dengan menyiapkan perangkat pembelajaran. Perangkat pembelajaran yang dipersiapkan yaitu silabus, RPP dan media permainan ludo. RPP yang dibuat telah disesuaikan oleh kurikulum 2013. Selain silabus dan RPP juga dipersiapkan penilaian untuk akhir siklus dengan penilaian tes evaluasi berpikir kreatif.

Selanjutnya tahap pelaksanaan dilakukan untuk mengetahui kemampuan berpikir kreatif siswa pada pembelajaran Bahasa Indonesia dan IPS. Pembelajaran dilakukan pada siklus I dengan 2 pertemuan karena hasil yang didapat belum maksimal. Harus dilakukan siklus II dengan memperbaiki hasil tes evaluasi berpikir kreatif.

Kegiatan observasi dilakukan guru dalam sela-sela pembelajaran digunakan untuk mengamati siswa dalam melakukan proses berpikir kreatif saat bermain media ludo. Observasi juga dilakukan untuk menilai permainan ludo yang dilakukan siwa dalam kelompok untuk mengetahui siswa bermain dengan baik atau hanya ingin bermain-main saja.

Sedangkan kegiatan refleksi dalam penelitian ini siswa bersama guru melakukan refleksi pembelajaran yang dilakukan pada setiap akhir pembelajaran. Guru memberikan sebuah pertanyaan dan memancing siswa untuk mengasah kemampuan berpikir kreatif dalam pembelajaran yang berlangsung.

Pada akhir tahap kegiatan refleksi siswa diberikan evaluasi akhir. Berikut adalah hasil evaluasi berpikir kreatif dari prasiklus, siklus I, dan siklus II untuk muatan Bahasa Indonesia disajikan pada Tabel 1 berikut ini.

Tabel 1.Hasil Evaluasi Berpikir Kreatif Muatan Bahasa Indonesia

\begin{tabular}{|c|c|c|c|}
\hline Nilai & Prasiklus & Siklus I & Siklus II \\
\hline Jumlah skor & 1750 & 1834 & 1945 \\
\hline Rata-rata & 72,9 & 76,8 & 81 \\
\hline Siswa tuntas & 8 & 17 & 22 \\
\hline Tidak tuntas & 16 & 7 & 2 \\
\hline Kriteria & P.Bimbingan & Cukup & Baik \\
\hline
\end{tabular}

Sedangkan rekapitulasi hasil akhir evaluasi berpikir kreatif dari prasiklus, siklus I, dan siklus II untuk muatan IPS disajikan pada Tabel 2 berikut ini.

Tabel 2.Hasil Evaluasi Berpikir Kreatif Muatan

\begin{tabular}{lccc}
\multicolumn{1}{c}{ IPS } & & & \\
\hline \multicolumn{1}{c}{ Nilai } & Prasiklus & Siklus I & Siklus II \\
\hline Jumlah skor & 1730 & 1905 & 2073 \\
Rata-rata & 72 & 79,4 & 86,4 \\
Siswa tuntas & 10 & 19 & 22 \\
Tidak tuntas & 14 & 5 & 2 \\
Kriteria & P.bimbingan & Cukup & Baik \\
\hline
\end{tabular}

Berdasarkan Tabel 1 menunjukkan bahwa terdapat peningkatan rata-rata skor perolehan pada muatan Bahasa Indonesia dari prasiklus, siklus I, dan siklus II yaitu 72,9; 76,8; dan 81 . Selain itu terdapat peningkatan pada jumlah siswa yang tuntas dari total 24 siswa yaitu 8 siswa saat prasiklus, 17 siswa saat siklus I, dan 22 siswa saat siklus II.

Berdasarkan Tabel 2 menunjukkan bahwa terdapat peningkatan rata-rata skor perolehan pada muatan IPS dari prasiklus, siklus I, dan siklus II yaitu $72 ; 79,4$; dan 86,4 . Selain itu terdapat peningkatan pada jumlah siswa yang tuntas dari total 24 siswa yaitu 10 siswa saat prasiklus, 19 siswa saat siklus I, dan 22 siswa saat siklus II. Hasil ini sesuai dengan hasil yang diperoleh pada penelitiannya Rudyanto (2014) yang menyatakan bahwa kemampuan berpikir kreatif siswa tuntas secara individual dan mencapai ketuntasan klasil.

Peningkatan skor perolehan pada tes evaluasi akhir berpikir kreatif dari prasiklus, siklus I, dan siklus II baik pada muatan Bahasa Indonesia ataupun muatan IPS dikarenakan pembelajaran yang menyenangkan yaitu dengan menggunakan media pembelajaran ludo. Hal tersebut menjadikan siswa menyukai pembelajaran yang dilakukan, siswa lebih aktif meskipun masih ada beberapa siswa yang kurang aktif. Siswa lebih banyak menyampaikan pendapat dan berdiskusi dalam kelompoknya. Mahardi (2019) menyatakan bahwa permainan ludo sangat membantu siswa untuk 
berkonsentrasi dalam melakukan pembelajaran yang efektif. Permainan ludo dapat meningkatkan konsentrasi siswa sehingga mendukung peningkatan kemampuan berpikir kreatif siswa.

Berdasarkan hasil observasi awal guru belum menggunakan media dalam proses belajar mengajar. Padahal menurut Supriyono (2018) media pembelajaran sangat penting untuk mengembangkan kemampuan berpikir kreatif siswa. Minimnya penggunaan media dalam pembelajaran membuat suasana kelas kurang kondusif. Hal ini didukung oleh pendapat dari Zubaidah (2015) yang menyatakan suasana kelas yang ideal dapat membantu anak untuk berkonsentrasi dan melakukan kegiatan berpikir dengan baik. Selain dua hal yang telah dijelaskan, guru juga masih menggunakan metode ceramah yang berlebihan saat melakukan pembelajaran. Padahal di kurikulum 2013 menuntut siswa untuk lebih aktif sesuai dengan apa yang disampaikan oleh Raehang (2014) yang menyatakan pembelajaran yang aktif harus melibatkan siswa secara aktif dalam proses pembelajaran.

Hasil perolehan nilai pada setiap siklus mengalami peningkatan yang baik. Dapat dilihat dari tabel diatas perolehan nilai pada setiap siklusnya mengalami peningkatan sehingga kemampuan berpikir kreatif siswa dikatakan baik. Pada prasiklus pembelajaran belum menggunakan media dalam pembelajaran sehingga perolehan nilai belum maksimal. Dibandingkan dengan perolehan nilai pada siklus I.

Siklus I kemampuan berpikir kreatif siswa dipengaruhi oleh penggunaan media permainan. Sesuai dengan penelitian yang sudah dilakukan oleh Chabib, Djatmika, dan Kuswandi (2017) menyatakan bahwa media dapat membantu siswa dalam menemukan solusi dalam suatu permasalahan yang dihadapi. Pada silkus I ini apabila siswa tidak menemukan jawaban didalam bacaan siswa lebih memilih diam dan tidak melakukan proses berpikir secara kreatif lebih giat lagi. Hal tersebut disebabkan oleh siswa yang belum terlalu paham dengan penggunaan media ludo. Selanjutnya siswa masih malu-malu untuk bertanya. Menurut Magdalena (2018) penyebab siswa malu bertanya adalah takut saat menyampaikan pendapatnya dan kurang percaya diri.

Siklus II pembelajaran menjadi lebih menyenangkan dan siswa lebih aktif dalam berinteraksi. Aspek berpikir kreatif yang paling banyak menurut Fauziah (2011) adalah apek kelancaran melalui metode tanya jawab. Hal senada diungkapkan oleh Nada, dkk (2018) bahwa dengan berdiskusi dan bereksplorasi siswa dapat menemukan ragam jawaban yang dapat mengasah kemampuan berpikir kreatifnya. Kemudian siswa sudah bisa menyimpulkan materi bacaan dari penggunaan media ludo. Penggunaan media pembelajaran menurut penelitian yang dilakukan oleh Jihan, Reffiane, dan Arisyanto (2019) dapat memaksimalkan potensi siswa.

Penggunaan media ludo juga membentuk siswa untuk dapat bekerja secara kelompok. Karena menurut Khatimah, Utami, dan Sari (2016) yang menyatakan bahwa penerapan permainan ludo dapat membentuk sebuah karakter siswa antara lain sikap kejujuran, kekompakan dalam memainkan permainan, jujur dan teliti. Karena proses berpikir kreatif sangat diperlukan dalam setiap pembelajaran untuk menentukan solusi kreatif yang digunakan dalam memecahkan suatu permasalahan. Azizah dan Fitrianawati (2020) juga menyampaikan bahwa pertanyaan-pertanyaan disajikan dalam bentuk permainan Ludo membuat siswa antusias dan tidak bosan dalam pembelajaran.

Sedangkan penelitian yang dilakukan oleh sonia, dan Armani (2008) menyatakan bahwa permainan ludo dapat digunakan untuk memperbaiki hasil evaluasi yang kurang. Permainan ludo ini sangat membantu siswa untuk melakukan berfikir kreatif secara efektif karena siswa mampu menemukan solusi yang baik dalam menyelesaikan permasalahan. Sama halnya dengan yang dilakukan oleh Indah, Gamayanti dan Widyatama (2016) yang menyatakan bahwa permainan ludo membantu siswa untuk giat dalam berpikir kreatif. Penelitian yang dilakukan oleh Amrullah, Ibrahim dan Widodo (2017) berpikir kreatif meningkat apabila ide atau solusi yang diberikan dalam menyelesaikan masalah sudah tepat.

\section{SIMPULAN}

Permainan ludo dapat menjadi solusi untuk meningkatkan kemampuan berpikir kreatif siswa. Dengan menggunakan permaianan ludo siswa dapat menemukan solusi yang tepat dalam menyelesaiakan suatu masalah yang ada di pembelajaran Bahasa Indonesia dan IPS. Aspek keterampilan berpikir kreatif dalam tema 6 subtema 1 dengan menerapkan permainan ludo sebagai upaya meningkatkan kemampuan berpikir kreatif siswa menunjukkan hasil pada siklus I memperoleh rata-rata 76,79 pada muatan Bahasa Indonesia dan 79,73 pada muatan IPS. Sedangkan pada siklus II memperoleh hasil nilai Bahasa Indonesia dengan rata-rata 81 dan 86,37 pada muatan IPS. Sedangkan hasil dari permainan ludo memperoleh hasil pada siklus I 
sebesar $74 \%$ dan pada siklus II memperoleh hasil $82 \%$. Dengan demikian permainan ludo sangat efektif untuk meningkatkan berpikir kreatif siswa kelas V SDN Jakenan.

\section{DAFTAR PUSTAKA}

Azizah, A.N., \& Fitrianawati, M. 2020. Pengembangan Media Ludo Math Pada Materi Pecahan Sederhana Bagi Peserta Didik Kelas III Sekolah Dasar. WASIS : Jurnal Ilmiah Pendidikan, 1(1): 28-35.

Chabib, Moch., Djatmika, Ery Tri., dan Kuswandi, Dedi. 2017. Efektifitas Pengembangan Media Permainan Ular Tangga Sebagai Sarana Belajar Tematik SD. Jurnal Pendidikan, 2(7).

Fauziah, Yuli Nurul. 2011. Analisis Kemampuan Guru Dalam Mengembangkan Keterampilan Berpikir Kreatif Siswa Sekolah Dasar Kelas V Pada Pembelajran Ilmu Pengetahuan Alam. Edisi Khusus, (2).

Hapsari, Marlyana Dewi. 2015. Efektifitas Ludo Word Game dalam Meningkatkan Penguasaan Kata-Kata Bahasa Jepang di SMK Mitra Karya Mandiri Ketanggungan Brebes. UNNES

Indah, Ana Puspita., Gamayanti, Indria Laksmi., dan Widyatama, Rendra. 2016. Efektifitas Pencegahan Adiksi Video Game Menggunakan Ludo Game Untuk Siswa Sekolah Dasar. Berita Kedokteran Masyarakat, 32(9).

Jihan, Aprilia Nur Fajar., Reffiane, Fine., dan Arisyanto, Prasena. 2019. Pengembangan Media Ludo Raksasa Pada Tema Selalu Berhemat Energi Untuk Meningkatkan Motivasi Belajar Siswa Kelas IV Sekolah Dasar. Mimbar PGSD Undiksha, 7(2).

Khatimah, Husnul., Utami, Reski Dian., dan Sari, Ira Novita. 2016. DODO (Domino Ludo);Sarana Pendidikan Karakter Berbasis Pembelajaran Tematik Pada Diri Anak Sekolah Dasar Di Era Sustainable Development Goals. Jurnal Pena, 3(2)

Lestari, Karunia Eka dan Yudhanegara, Mokhammad Ridwan. 2015. Penelitian Pendidikan Matematika. Karawang: PT Rafika Aditama.
Magdalena, Mariam. 2018. Melatih kepercayaan Diri Siswa Dalam Menyatakan Tanggapan Dan Saran Sederhana Melalui Penguatan Pujian Pada Pembelajaran Bahasa Indonesia. KIBASP, 1(2).

Mahardi. 2019. Permainan Ludo Sebagai Media Pembelajaran Pendidikan Jasmani Dan Kesehatan Pada Siswa Sekolah Dasar. Jurnal Sport Sciences And Physical Education, 7(2).

Munandar, Utami. 2014. Pengembangan Kreativitas Anak Berbakat. Jakarta:Rineka Cipta

Mursidik, Elly's Mersina., Samsiyiah, Nur., dan Rudyanto, Hendra Erik. (2015). Kemampuan Berpikir Kreatif Dalam Memecaahkan Masalah Matematika Open-Ended Ditinjau Dari Tingkat Kemampuan Matematika Pada Siswa Sekolah Dasar. Journal Pedagogia, 4(1).

Nada, I., Utaminingsih, S., \& Ardianti, S.D., 2018. Penerapan Model Open Ended Problems Berbantuan CD Pembelajaran Untuk Meningkatkan Kemampuan Berpikir Kreatif Siswa Kelas IV SD 1 Golantepus. Jurnal Pendidikan Sekolah Dasar, 4(2): 216-227

Raehang. 2014. Pembelajaran Aktif Sebagai Induk Pembelajaran Koomperatif. Jurnal AL-Ta'dib, 7(1).

Rhosalia, Lulu Anggi., Laksono, Kisyani., dan Sukartiningsih, Wahyu. 2016. Kemampuan Berpikir Kreatif Menulis Naratif Siswa Kelas V Sekolah Dasar Negeri Di Kecamatan Guyangan Surabaya. Jurnal Review Pendidikan Dasar, 2(2).

Rudyanto, Erik Hendra. 2014. Model Discoveri Learning Dengan Pendekatan Scientifik Bermuatan Karakter Untuk Meningkatkan Kemampuan Berpikir Kreatif. Premiere Educandum, 4(1).

Sonia, Anna Tovni dan Armaini. 2018. Pengaruh Media Ludo Word Game (LWG) Untuk Meningkatkan Kosakata Bagi Anak Tunarungu. Jurnal Penelitian Kebutuhan Khusus, 6(1).

Supriyono. 2018. Pentingnya Media Pembelajaran Untuk Meningkatkan Minat 
Visca Elya Anastasya, Ristiyani, dan Nur Fajrie

PERMAINAN LUDO SEBAGAI UPAYA MENINGKATKAN KEMAMPUAN BERPIKIR .... WASIS: Jurnal Ilmiah Pendidikan. Volume 2 Nomor 1, Mei 2021, hlm. 9-14

Belajar Siswa SD. Jurnal Pendidikan Dasar, 2(1).

Wulandari, Fitriana Ayu., Mawardi., dan Wardani, Krisma Widi. 2019. Peningkatan Kemampuan Berpikir Kreatif Siswa Kelas V Menggunakan Model Mind Mapping. Jurnal Ilmiah Sekolah Dasar, 3(1).

Zubaidah, Enny. 2015. Pemanfaatann Media Pembelajaran Untuk Menciptakan Lingkungan Kelas SD (Alternatif Penciptaan Laboratorium SD yang Efektif. Jurnal Prima Edukasia, 3(1). 